\title{
Erratum to: Scandinavian Cooperative Advantage: The Theory and Practice of Stakeholder Engagement in Scandinavia
}

\author{
Robert Strand • R. Edward Freeman
}

Published online: 9 November 2013

(C) Springer Science+Business Media Dordrecht 2013

\section{Erratum to: J Bus Ethics \\ DOI 10.1007/s10551-013-1792-1}

During the publishing process of this article two important references were omitted. Here we correct the missing citations within the body of the text and offer the full references thereafter.

' $\mathrm{xxxx}$ ' was incorrectly listed as a citation where this should have instead read 'Mackey and Sisodia 2013.' The corresponding corrected sentence reads as follows: "It would seem that Scandinavian stakeholder capitalism is a closer model to 'conscious capitalism' (Mackey and Sisodia 2013) than is experienced elsewhere, such as the U.S."

The sentence with reference to Lakoff and Johnson (1980) was also incorrectly omitted. The corrected passage reads as follows: "We thus encourage a concerted move toward a focus on achieving a cooperative advantage and a corresponding use of more cooperation-based language and metaphors in the strategic management field. See Lakoff and Johnson (1980) for discussion regarding how the language and metaphors we use shape our perceptions of reality and subsequent actions."

\section{References}

Lakoff, G., \& Johnson, M. (1980). Metaphors we live by. Chicago: University of Chicago Press.

Mackey, J., \& Sisodia, R. (2013). Conscious capitalism: Liberating the heroic spirit of business. Cambridge, MA: Harvard Business Press.

The online version of the original article can be found under doi:10.1007/s10551-013-1792-1.

R. Strand $(\bowtie)$

Copenhagen Business School, Porcelænshaven 18A,

Ground Floor, 2000 Frederiksberg, Denmark

e-mail: rs.ikl@cbs.dk

\section{R. E. Freeman}

University of Virginia Darden School of Business, 100 Darden

Boulevard, Office: FOB 164, Charlottesville, VA 22903, USA

e-mail: freemane@darden.virginia.edu 